\title{
Minimum Wage Research, a Methodological Path: A Social Institution and a Hidden Growth Factor
}

\author{
Maria Georgia Antonopoulou \\ Department of Sociology, Panteion University of Social and Political Science, Athens, Greece \\ Email address: \\ mgantonopoulou@yahoo.gr

\section{To cite this article:} \\ Maria Georgia Antonopoulou. Minimum Wage Research, a Methodological Path: A Social Institution and a Hidden Growth Factor. \\ Humanities and Social Sciences. Vol. 9, No. 3, 2021, pp. 74-79. doi: 10.11648/j.hss.20210903.13
}

Received: May 18, 2021; Accepted: June 7, 2021; Published: June 16, 2021

\begin{abstract}
The article aims to demonstrate the methodological constraints that arise from social science research into the minimum wage. We exam the functionality and the various theoretical approaches as to its usefulness and way of implementation especially in the European Union before and after the 2008 economic crisis. The working hypothesis is that minimum wage has been used for most countries up until now as a growth factor, operating as "treatment" to the distortions of the open market economy. We first feature a historical approach of the minimum wage policies, then we discuss the main methodological concerns around the subject focusing on the EU new economic policies in the aftermath of the 2008 crisis. In this context we also discuss the harmonized policies of a European minimum wage framework as well as the motion for a living wage. Then the article focuses to the policies driven during the pandemic. We found that during the COVID-19 crisis we had a paradigm shift in the European Union as well as in USA, from the strict neoclassical economic policies to more inclusive ones. Concluded that the minimum wage is a social policy institution, while at the same time being considered as part of the wage policy regulated by the free market. The minimum wage has a dual role, while it is part of economic policy, so it is generally determined by the free market and the social partners, at the same time it is called to cure distortions that the free market itself creates in the most vulnerable social strata.
\end{abstract}

Keywords: Minimum Wage, Neoliberalism, Social Policy, 2008 Crisis, Living Wage

\section{Introduction}

The following article aims to demonstrate the methodological constraints that arise from social science research into the minimum wage. The international economic crisis of 2008 and the social and political impact to the western world and beyond, brought the return of a public debate around the institutions and the tools used to manage the social consequences of a crisis, which until recently were taken for granted and considered outdated as to their efficiency.

Since the early 1990s the discussion about the minimum wage amongst the scientific community made a strong come back, although it remained firmly amongst the economic field, mainly focusing on the consequences of the minimum wage in relation to the employment of women and the young. The social and political sciences were almost absent during the scientific debate, an occurrence with various interpretations. Indeed, the range of the social consequences from the 2008 crisis and the mixture of policies from the European institutions and international organizations, that brought at the forefront cumulative changes in the labour market, refocuses the context of the scientific research and public debate.

The subject of the current article is the methodological approach by social science into the issue of minimum wage, examining the functionality and the various theoretical approaches as to its usefulness and way of implementation. The working hypothesis is that minimum wage has been used for most countries up until now as a growth factor, operating as "treatment" to the distortions of the open market economy and not as a social institution that safeguards the social and political rights of the most vulnerable working groups. The first part of the article presents the historical approach to the minimum wage, the second part follows the discussion of the main methodological concerns around the subject and the third part presents the conclusions. 


\section{Minimum Wage History Review}

The notion of the minimum wage was first introduced in New Zealand and Australia during the 1890's. The way it was first implemented and the reasons behind its introduction bear already the dualism that can be traced in the research and in the practice of the states until today. The formation of the minimum wage, way before the beginning of the $20^{\text {th }}$ century and all the way to the present time has been based on the same three models, free collective bargaining, tripartite negotiations, and state intervention. In New Zealand specifically, the minimum wage was introduced in manufacturing as part of the Industrial Conciliation and Arbitration Act. At the joint councils between the trade unions and employer's organizations, a minimum fee was established per sector with the ability to extend into an industry level. In 1899 New Zealand modified the sectoral system and introduced a state set minimum wage which would be applied throughout the country. Meanwhile from 1896 Australia set the minimum wage as the subject of tripartite negotiations. The original cause for the introduction of the minimum wage in New Zealand and Australia aimed at the protection against non-paid and under paid labour from children, apprentices, and the protection of workers in the low wages manufacturing sector, the so- called sweatshops factories [22].

The example set by these countries was followed at the beginning of the $20^{\text {th }}$ century by several regional countries. The United Kingdom had already adopted a minimum wage since 1909 but in a limited way involving only four sectors, those judged to be more prone to underpaid work and it was determined through tripartite negotiations, following the Australian standards. In the USA, the minimum wage enters through legislation «from the top», initially in the state of Massachusetts in 1912. By the time the Fair Labour Act from Roosevelt in 1938 was in place, many states had already proceeded into adopting the new practices as means of protecting employment. However, it is the total framework of the New Deal policy that forms the terms for a state regulation on a minimum wage for employees. The social contract on which the flourishing American economy was based, the metropolis of capitalism, attempted to regulate the employment environment so on the one hand to stimulate production and work efficiency, while on the other to reduce market dysfunctions that would emerge from industrial action and the rising tensions of the competing social classes [10]. In the Treaty of Versailles, specifically in Part 8, we come across the charter of the International Labor Organization, indicative of the need for international cooperation both in the economic and social fronts acting as a deterrent for a potential new war. The first point of reference in an international text for the need to establish a minimum threshold on workers' salaries, is found in 427 articles of the Official Bulletin, «the payment to the employed of a wage adequate to maintain a reasonable standard of living as this is understood in their time and country» [18], while in 1928 at the International Labor Convention 26, for the first time there is the description of a regulating mechanism for the minimum wage ([21], p. 2). During the decades 1960-1970 several important International Treaties (European Social Charter, 1961, the International Labor Convention 131, 135 of 1970) revisit the issue, considering the creation of a minimum wage as a fundamental social right. The revised European Social Charter of 1998 sets the minimum wage in article 4.1, as a right to fair remuneration « the Parties undertake to recognise the right of workers to a remuneration such as will give them and their families a decent standard of living [...] The exercise of these rights is achieved by freely concluded collective agreements, by legally established wage-setting mechanisms, or by other means appropriate to national conditions» (N. 4359/2016, 2016). In the 20 principles of the European Pillar of Social Rights 2017, which constitutes a soft law text, the reference to the minimum wage becomes more precise in article 6, "Adequate minimum wages shall be ensured, in a way that provide for the satisfaction of the needs of the worker and his/her family in the light of national economic and social conditions, whilst safeguarding access to employment and incentives to seek work. In-work poverty shall be prevented $»^{1}$. The International Labor Organization refers in $131 / 1970$ Recommendation article 2, that the minimum wage should be forced by law, while in article 3 sets the minimum criteria required $^{2}$. The most important points of the declaration are summarized in the following conclusions; firstly, the institution of the minimum wage does not only concern the respective employee but also their family; secondly components of its formation and implementation are the consultations between the social partners; third the criteria for its increase would be made up by combining the risk of poverty and their livelihood needs along with development and productivity [21]. Most European countries have introduced the minimum wage before 2008, while over $90 \%$ of the countries who are members of the W.T.O. have some form of established minimum wage. An interesting element is that from 2010 there is stronger state interference in its development and gradual weakening of the role of free collective bargaining.

In Germany, the minimum wage was introduced only in 2015, after lengthy consultations amongst social partners as well as between the two major political parties of the German parliament. To determine the amount, the German government established a permanent committee (Mindestlohn Commission). The committee is appointed for a five-year term, its members work without pay, and the committee's decisions are ratified by the federal government. In accordance with German law, minimum wage contributes to the provision of the appropriate minimum level of protection for workers, guarantees fair and operational

\footnotetext{
1 https://ec.europa.eu/commission/priorities/deeper-and-fairer-economic-andmonetary-union/european-pillar-social-rights/european-pillar-social-rights-20principles_el\#relatedlinks

2

https://www.ilo.org/dyn/normlex/en/f?p=NORMLEXPUB:12100:0::NO:12100:P 12100_INSTRUMENT_ID:312276:NO
} 
competitive terms and avoids jeopardizing employment. (Article 6, Paragraph 39, Section 6, BGBI. I S. 872). To conclude, the minimum wage is understood to be the minimum amount of fair remuneration required towards employees, ensuring an adequate standard of living, preventing poverty, while all social partners are called upon to have an input in shaping it.

\section{The Minimum Wage During the Crisis}

The global financial crisis of 2008 brought changes in the working conditions, especially within the European Union. The fiscal adjustment programs that were implemented (Greece, Portugal, Spain, Cyprus, Ireland) as well as the management of the debt crisis through internal devaluation, reformed the actual employment relations but more importantly questioned the European Social Acquis. In practice this also appears on the 2017 Proclamation of the European Pillar of Social Rights. The scale of the minimum wage must be determined considering the needs of the employees as well as the current macroeconomic factors such as productivity. Thus, the debate shifts for the first time from the protection of the workers and their families' basic needs to the adequacy of fiscal and macroeconomic indicators. The social role of safeguarding a minimum wage gets limited by monetary stability. The shift of the debate from sustainable development and social welfare (SEE article 2-5/1992) to securing specific macroeconomic indicators is indicative of the big changes that took place at a political level during the modern-day Great Depression. The discussion about the minimum wage within the member states and the EU institutions focuses on the question as to what is more important, the macroeconomic analysis with the rigid fiscal targets that sets as aim and condition for achieving the required economic growth competitiveness in terms of economy and wages or the social protection of all employees, job creation with decent pay and high standards of living. Our theoretical research starting point is based on the Espring -Andersen concept of decommodification of labour within a communal social area [1]. The reforms regarding the minimum wage and its dynamic in the post crisis era are going through an institutional decommodification of labour and a shift that views social policy not just as a solution but as a prerequisite for development.

Indicative of the changes that took place at EU level is the fact that while the European Pillar of Social Rights includes the declaration for the necessity to safeguard the minimum wage, this remains purely on a pronouncement level, part of a soft law, while, based on the internal interpretation of the text according to the Commission, the scale of the minimum wage should be in correlation with the economic productivity and other financial parameters at the time [12]. It is worth pointing out that both the article as well as its interpretation are contradicted in the reports of ILO which calls upon its members to take specific measures, even to apply sanctions to safeguard the minimum wage [18]. The restrictive framework in the labour market, labour rights and the wage policy as set by the new EU economic governance, occupies already a large place in literature.

The main conclusions converge, that the policies of fiscal discipline as the answer to the economic crisis are based on internal devaluation through the reduction in the cost of labour $[12,15]$. Opposing views seem to argue that the reduction of labour costs was not due to the crisis and the new economic governance but rather the result of a significant increase in several countries in the period before 2000- 2009. The debt crisis and the policies chosen to deal with it, encouraged wage convergence amongst European economies, forcing some member states to reduce previous labour costs to balance the great differences across the EU, aiming at the competitiveness of the national and European economy $[15,16]$.

The resurgence of the scientific debate within the European Union regarding the minimum wage introduced new qualitative data about its scale. In addition, both the ILO and the OECD have brought back their proposal for the creation of a general minimum wage set at the $60 \%$ of the median. This measure, if applied, will lead to a significant rise in the current minimum wage for most Eastern European countries as well as those in the South of Europe.

In recent years, the proposal to achieve a harmonized minimum wage policy at European level is gaining momentum, namely the introduction of a commonly shaped European minimum wage $[23,25,14,20]$. A feature of this new trend is the framework directive proposed by the Commission on minimum wage ${ }^{3}$. Such an initiative could act in line with the policies for the guaranteed minimum income of the lower social strata. This protection, depending on the criteria that will determine the amount of the minimum wage, and therefore the poverty line, could actively contribute to the social dimension of the minimum wage. In other words, if the minimum wage is $60 \%$ of the median, as suggested by several international organizations (OECD, ILO), the main criteria would be the provision of a salary that covers basic living standards and well-being. The term well-being in this case does not just solely mean the cover of the basic biological needs but more important the cover of main social needs [2]. The difference between the biological and social needs is, after all, the striking contrast between social protection and neoliberal orthodoxy to achieve competitiveness by reducing wage costs. As Betsy Jane Clary [5] states, the social understanding of the minimum wage ultimately involves its scale and the economic policy of each government. It is precisely this social dimension of wages that serves as a boost to social and economic progress, which contrasts with the neoclassical strategy with which the EU sought to resolve the 2009-2015 economic crisis. The policy of setting the minimum wage during the pandemic follows two different strategies, in the countries of the South we have its reduction (Greece) or its freezing and its disconnection from the social dialogue (Spain, Portugal) while on the

3 https://ec.europa.eu/commission/presscorner/detail/en/ip_20_1968 
contrary in the strong pillar of the EU, the state of Germany, we have its introduction under pressure from the Social Democrats and the unions. The minimum wage in this case restrained any possible reduction by stabilizing wages acting as a measure of minimum social cohesion.

The neoliberal response to the debt crisis in Eurozone provoked a series of social and political reactions, which aim not to challenge the stability of the monetary union but the project of European integration itself, including protesting in squares and the rise of the far right in most European countries. The institutionalization of the minimum wage in Germany, which was kept by the central European member states at high levels and its large increase in comparison with the Southern member states that were under fiscal adjustment programs, can also be justified by political terms.

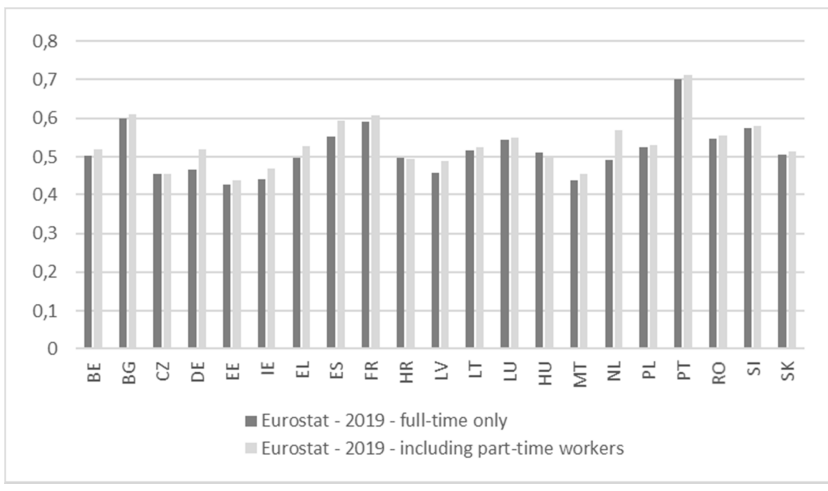

Figure 1. Minimum wages, expressed as a percentage of the gross median wage, 2019 - full-time workers only and part-time workers included.

Source: Eurostat (2020) (Commission, Proposal for a directive of the European Parliament and of the Council on adequate minimum wages in the European Union. Impact Assessment) (Anker \& Anker, 2017).

Minimum wages, January 2011 and January 2021 (EUR per month and \%)

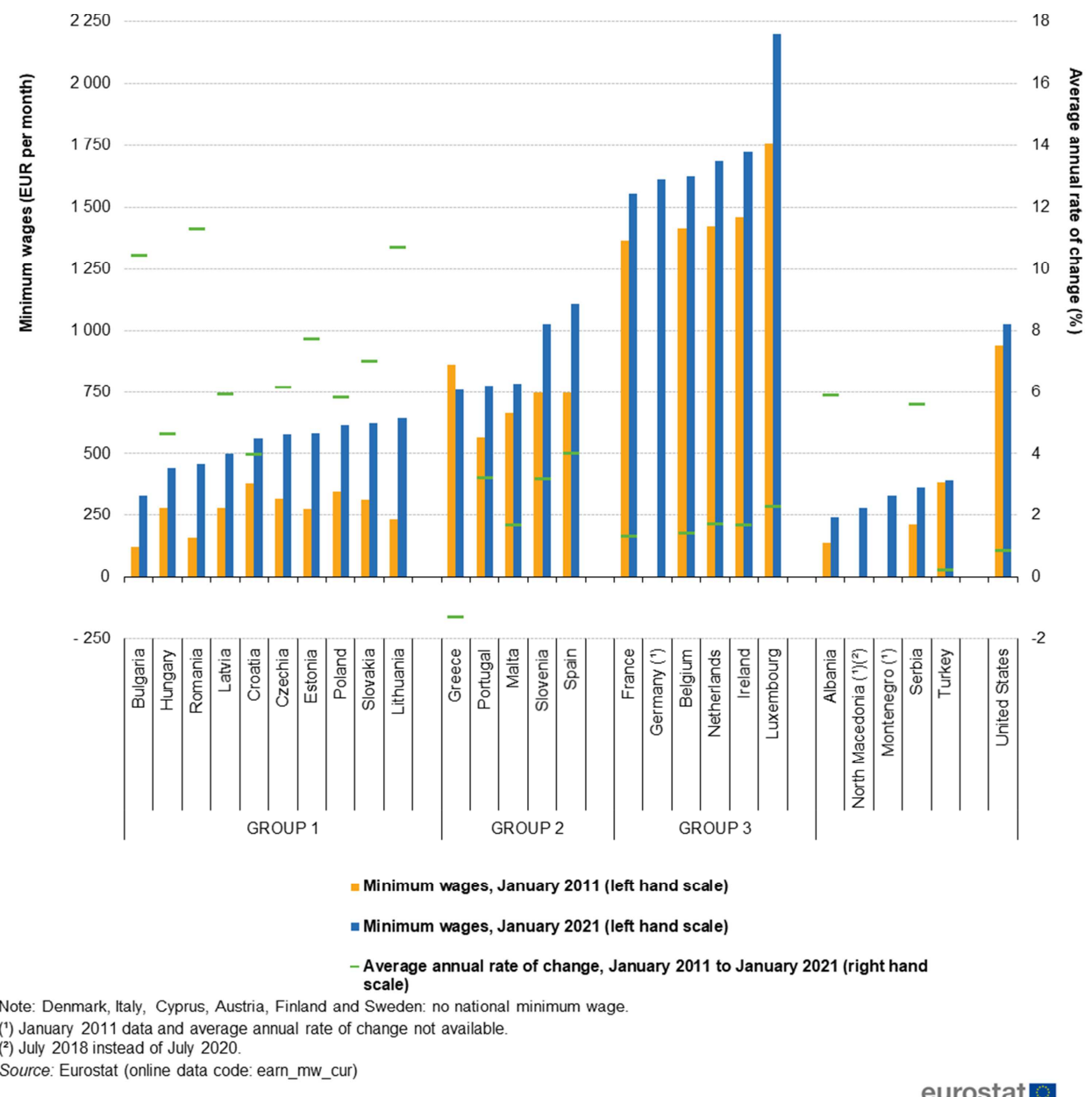

Source: Eurostat ${ }^{4}$

Figure 2. Minimum Wages during the Decade 2011-2021 in EU-27. (euro per month and \%). 
This, however, calls into question the policies pursued to increase competitiveness by reducing labour costs. Political stability and social cohesion are parts of the founding Treaties of the EU, factors that promote sustainable economic growth, but the economic policies followed not only do not contribute to this direction but on the contrary aggravate social dissatisfaction and worsen the financial situation of the poorest in the countries of the South during the imposition of impoverished domestic measures focusing on the minimum wage and collective bargaining [3].

\section{The Coronavirus Crisis as a Steppingstone to a More Social Europe}

The debt crisis of 2008-2015 was attempted to be resolved by adhering to neoclassical economics, insisting on maintaining austerity and strict fiscal data, pursuing a tight monetary policy, and reducing labour costs to increase productivity. However, European integration deepened as its economic policy and especially the banking and monetary systems took steady steps towards a greater degree of cooperation [11].

The greatest blow though during the crisis, was to the European welfare state and especially the lower paid, as the minimum wage either fell or remained at the same levels for over 5 years. The coronavirus crisis which has pounded European economies - especially in the South - is being tackled with a different mix of economic policies. A sign in this shift is the fact that the President of the Commission as early as October 2020 proceeded to declare a directive for adequate minimum wages for workers across Member States with the aim: "Improving working and living conditions will not only protect our workers, but also employers that pay decent wages, and create the basis for a fair, inclusive and resilient recovery" ${ }^{\prime \prime}$. The dialogue that takes place after this decision, mainly on the part of the employers, reinforces the dualism that we have highlighted in this text. The objections raised by the representatives are mainly concentrated on the need to ensure equality and decent wages but without the involvement of the EU institutions in defining national frameworks for wage policy ${ }^{6}$. This demonstrates the contradiction, that the minimum wage is the subject of social policy and thus of state care, while at the same time being considered as part of the wage policy regulated by the free market.

In conclusion, the minimum wage has a dual role, while it is part of economic policy, so it is generally determined by the free market and the social partners, at the same time it is called to cure distortions that the free market itself creates in the most vulnerable social strata. During the financial crisis of 2008 and especially in the European South, the minimum wage functioned as the main mechanism of the attempted internal devaluation. On the contrary, when the negative

5 https://ec.europa.eu/commission/presscorner/deta/en/ip_20_1968

$6 \mathrm{https}$ ://euobserver.com/opinion/151327 effects of neoliberal policies became apparent, the debate shifted from both the OECD and the EU leadership to the therapeutic use of the minimum wage. So, the Commission proposed in 2020 during the COVID-19 crisis the determination of a common European framework while the OECD restores the radical proposal to set it at $60 \%$ of the median.

\section{References}

[1] Andersen, E. (1990). The Three Worlds of Welfare Capitalism. Princeston University Press.

[2] Anker, R., \& Anker, M. (2017). Living Wages around the World: Manual for Measurement. Edward Elgar Publisher.

[3] Ayala, L., Garcia-Serrano, C., \& Martinez-Virto, L. (2021). The Effectiveness of Minimum Income Benefits in Poverty Reduction in Spain. International Journal of Social Welfare, 152-169.

[4] Clary, B. J. (2009). Smith and Living Wages: Arguments in Support of a Mandated Living Wage. American Journal of Economics and Sociology, 1063-1084.

[5] Commission, E. (2010). Council Recommendation on broad guidelines for the economic policies of the Member States and of the Union. Part I of the Europe 2020 Integrates Guidelines. European Commission.

[6] Commission, E. (2011). Labor Market Developments in Europe, 2011. European Economy.

[7] Commission, E. (2012). Labor Market Developments in Europe 2012. European Union.

[8] Commission, E. (2020). Proposal for a directive of the European Parliament and of the Council on adequate minimum wages in the European Union. Impact Assessment. Brussels: European Commission.

[9] Douglas, P. (1938). The Economic Theory of Wage Regulation. University of Chicago Law, 5 (2), 184-218.

[10] Eichengreen, B. (2014). The Eurozone Crisis: The Theory of Optimum Currency Areas Bites Back. Notenstein Academy White Papers Series.

[11] Featherstone, K. (2015). External Conditionality and the Debt Crisis: The "Troika" and Public Administration Reform in Greece. Journal of European Public Policy, 22 (3), 295-314.

[12] Fric, K. (2018). Industrial Relations. Statutory Minimum Wage. Luxembourg: EUROFOUND.

[13] Garnero, A., Kampelmann, S., \& Rycx, F. (2014, August). Minimum Wage Systems and Earnings Inequalities: Does Institutional Diversity Matter? Discussion Paper No. 8419.

[14] Gyes, G., \& Schulten, T. (2015). Wage Bargaining under the new European Economic Governance. ETUI.

[15] Höpner, M. S. (2018). Transnational Coordination for Stabilization of the Euro? There wasn't, there wasn't, there wasn't going to be. Cologne Description for Sociology and Sociopsychology (in German), 70, 414-437. 
[16] IMF. (2015). World economic outlook: Adjusting to lower commodity prices. Washington, DC: International Monetary Fund.

[17] International Labor Office. (1923). Part XIII of the Treaty of Peace of Versailles. Geneva.

[18] International Labor Office. (2014). Minimum Wage Systems. International Labour Conference, 103rd Session. ILO.

[19] Ioannou A., C. (2019). Collective Bargaining decentralization and wage adjustment for internal devaluation. In: $H$. Voskeritsian, P. Kapotas, \& C. Niforou, Greek Employment Relations in Crisis. Problems, Challenges and Prospects. New York: Routledge.

[20] Müller, T. S. (2019). An end to wage policy interventionism? Perspectives for a wage policy orientation in Europe. In: N. Soukup, Neoliberal Union or Social Europe? Approaches and obstacles to a social realignment of the EU (In German). Wien. 55-79.

[21] Marinakis, A. (2009). The Role of ILO in the Development of Minimum Wages. Santiago: ILO.

[22] Neumark, D., \& Washer, W. L. (2008). Minimum Wage. Cambridge, London: The MIT Press.

[23] Schulten, T. (2012). European Minimum Wage Policy: A Concept for Wage-Led Growth and Fairs Wages in Europe. International Journal of Labour Research, 4 (1), 85-103.

[24] Schulten, T. M. (2013). A New Interventionism? The Impact of the New Economic Governance on Wages and Collective Bargaining. $\Sigma \tau$ o N. V. David, Social Developments in the European Union 2012). Brussels: ETUI, 181-213.

[25] Schulten, T., Bispinck, R., \& Schäfer, C. (2006). Mindestlohne in Europa. Hamburg: VSA-Verlag. 